\title{
Design of Facultative Pond for the Treatment of Industrial Waste Water in Urban Settlement
}

\author{
*Okonofua, E. S., \& Oghoyafedo, N. K. \\ Department of Civil Engineering, Faculty of Engineering, University of Benin, Benin City, Nigeria \\ *Corresponding author's e-mail: ehizonomhen.okonofua@uniben.edu
}

\begin{abstract}
This study evaluated the degree of pollution of Ikpoba River due to the incessant discharge of industrial wastewater into the river. The entire study area was digitised and geo-referenced in order to generate the map of the study area as well as the sampling points. Eight (8) water samples were obtained from different locations from the direction of flow of industrial discharge into the river and also within the river. The coordinate of the sample collection points were acquired using handheld geographic positioning system (GPS). Water samples for physicochemical analysis were collected in a clean sterilized plastic container and analysis were carried out in the laboratory following standard procedure. The environmental variables measured were dissolved oxygen (DO), total suspended solid (TSS), pH, total dissolved solid (TDS), turbidity, concentration of nitrate and nitrite, chloride, phosphate, zinc, barium, tin, biological oxygen demand (BOD), conductivity, manganese, magnesium, calcium etc. Results obtained showed that most parameters investigated had increasing values. The calculated water quality index (WQI) from the sampling points ranged from 40.02 to 52.62, which indicates that most of the samples are bad as classified using National Sanitation Foundation (NSF) standard. This study therefore recommends that water quality around areas of industrial wastewater discharge in Ikpoba hill should be monitored and adequate treatment recommended where necessary.
\end{abstract}

Received 4 Dec. 2018; Revised 8 Jan. 2019; Accepted 11 Jan. 2019; Available online 1 Feb. 2019. Copyright (C) 2019 The Authors. This is an open access article under the CC BY-NC-ND license (http://creativecommons.org/licenses/by-nc-nd/4.0/)

\section{Introduction}

Urbanisation, industrial development and civilisation have always taken place along river routes, lakes streams and other water bodies (sources). Water supply to communities, towns, industries and agricultural settlements, have for a long time become essential for humans in attempt to develop a comfortable environment. In this regard, water from natural sources are harvested and harnessed to achieve this purpose. The sources mostly preferred are those with little or no contamination in the water cycle. Varieties of man's activities tend to contaminate water sources a great deal. With increase industrialisation, industrial wastewater appears to be one of the greatest pollution source to surface water in the globe (Bichi, 2015).

Current researches (Anandalingam \& Westfall, 2017; Hardoy et al., 2012) showed that there is severe pollution of water bodies and degradation in industrialised countries across Europe, Japan and northern America. This challenge is of great concern as various researches in Africa, parts of Asia and southern America have equally reported devastating water contamination challenges similar to that of industrialised nations (CSE, 2013; ESCAP, 2011; Oluruntola, 2012; UNEP 2017). Water resources contamination challenges exhibits themselves in the different uses to which the water is subjected to. These different uses transfer several contaminants such as $\mathrm{Pb}, \mathrm{Cd}, \mathrm{Co}, \mathrm{Hg}$ etc. in the environment into the water. According to Aikman (2013), irrigation water contaminated with heavy metals can result in crop death, prevent absorption of essential minerals or form clog in fruits thereby rendering them toxic to man and grazing animals; these contaminants are also found in sea animals, which is also a source of food for man. The results of recent World Bank study (Bichi, 2013) showed that 45\% of sampled fishes and shellfish in Jakata

Article citation: Okonofua, E. S., \& Oghoyafedo, N. K. (2019). Design of Facultative Pond for the Treatment of Industrial Waste Water in Urban Settlement. Journal of Advances in Science and Engineering, 2(1): 9-15. https://doi.org/10.37121/jase.v2i1.35 
Bye exceeded WHO limits for Lead, 38\% exceeded mercury while 76\% exceeded Cadmium. In a stream in Ikot Epene, which serves as drinking water for downstream settlers; heavy metal were found in fishes caught in the stream. In 2011, UNEP/WHO monitored water contamination in 345 stations within Global Environmental Monitoring System; the result showed that one-quarter of the station had Cadmium exceeding guideline limits (Leonard, 2004).

The most adverse effect of toxic metal contamination in water is that at higher levels of concentration, they are poisonous and have detrimental effect on plants, animals and man (Gidding, 2003). Recent water pollution researches in developing nations suggests the increasing danger of water poisoning to man leading to uncountable deaths. Hardoy et al. (2012) reported high concentration of mercury in some streams in industrialised parts of Kano state; several people were reportedly poisoned by consuming fishes caught in the river, which had higher Mercury concentration. Pathogenic organism and insect vectors thrives and breeds in filthy environment where there is indiscriminate discharge of waste. These vectors are snails, mosquitoes, flies and bugs while the pathogens are microbes, virus, fungi, bacteria and protozoa; these are the agents causing water borne diseases, which often leads to epidemics (Dawood, 2016). Diarrhoea a water borne is solely responsible for over 35\% of death in age five years and below in Pakistan (Gibbs, 2017). There are also increased cases of water borne diseases in draining sewage and waste sites in Kano and Benin City (Bichi, 2013). Filthy environment, odour and uncontrolled waste disposal can also affect the health status of the people within the environment. The aim of this paper is to design a treatment pond (facultative) for the treatment of industrial wastewater from breweries before discharged into Ikpoba stream.

\section{Materials and Methods}

Two brewery industries (Bendel Brewery and Guinness Nigeria Plc.) are sited within Oregbeni community of Benin City, Edo State; but only Guinness Nigeria Plc. was operational at the time of this study. Ikpoba River is a fourth order stream, located in Benin City, in South Western Nigeria. The coordinate of the headwater is within Latitude $6.5^{\circ} \mathrm{N}$, Longitude $5-8^{\circ} \mathrm{E}$ and it comes from north-western direction in Benin City and flows southwards into the city (Benka-Coker \& Ojior, 2015). The river passes through thick rain forests where allochotonous infusions of organic matters from the border vegetation are obtained by runoff from soil surface. Benin Basin system, the third largest in Nigeria, receives runoff from Ikpoba River, which serves as a major source of drinking water and for other domestic uses for the downstream settlers who also use it for fishing.

Ikpoba River collects different forms of wastes from agricultural deposits, domestic, industrial and commercial sources. These refuges bring toxic, microorganisms, organic and inorganic matters into the river. The waste products from the various breweries activities, which usually have large wastewater volumes are transported through underground channels of about $2.5 \mathrm{~km}$ and emptied directly into Ikpoba River (Ekhaise \& Anyasi, 2011). Production and marketing of various brands of beer is the sole activity in these breweries. Effluent in variant compositions but with a common characteristic of high organic matters is generated in the course of production. This is responsible for the growth of vegetation within the wastewater discharge location.

\subsection{Study Design}

This study was carried out to ascertain the physicochemical quality of the effluent from a point source before entering the river and at the point of release. The quality of the river water at both upstream and downstream locations will be evaluated. Reconnaissance wastewater survey was carried out to determine suitable sampling points. These points were chosen based on accessibility and taking cognisance of the wastewater courses from the two major breweries to the final discharge points. Also, during the survey, handheld GPS was used to obtain coordinate of the river extent within the study area that was used in producing the map of the study area as shown in Figure 1.

\subsection{Sampling Points and Geo-locations}

Eight samples were taken at the discharge points for Guinness brewery into Ikpoba River and at some other locations along the reach of the river. The location was carefully chosen so as to prevent delay in taking samples to the laboratory for analysis. Handheld GPS was used to obtain the coordinates of the wastewater sampling points. Table 1 shows sampling locations within the river channel. 
Table 1. Summary of Geo-locations for sampling points

\begin{tabular}{|c|c|c|}
\hline Sample Code & Northing & Easting \\
\hline DP 1 & N06 $20^{\prime} 016^{\prime \prime}$ & $\mathrm{E} 005^{\circ} 39^{\prime} 880^{\prime \prime}$ \\
\hline $\mathrm{DP} 2$ & N06 $20^{\prime} 019^{\prime \prime}$ & $\mathrm{E} 005^{\circ} 39^{\prime} 870^{\prime \prime}$ \\
\hline DS-1 & N06 $20^{\prime} 024^{\prime \prime}$ & $\mathrm{E} 005^{\circ} 39^{\prime} 829^{\prime \prime}$ \\
\hline DS 1 & N06 $20^{\prime} 004^{\prime \prime}$ & $\mathrm{E} 005^{\circ} 39^{\prime} 894^{\prime \prime}$ \\
\hline DS 2 & N06 $20^{\prime} 019^{\prime \prime}$ & $\mathrm{E} 005^{\circ} 39^{\prime} 918^{\prime \prime}$ \\
\hline DS 3 & N06 ${ }^{\circ} 20^{\prime} 034^{\prime \prime}$ & $\mathrm{E} 005^{\circ} 39^{\prime} 942^{\prime \prime}$ \\
\hline DS 4 & 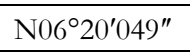 & $\mathrm{E} 005^{\circ} 39^{\prime} 966^{\prime \prime}$ \\
\hline DS 5 & N06 $20^{\prime} 064^{\prime \prime}$ & $\mathrm{E} 005^{\circ} 39^{\prime} 900^{\prime \prime}$ \\
\hline
\end{tabular}

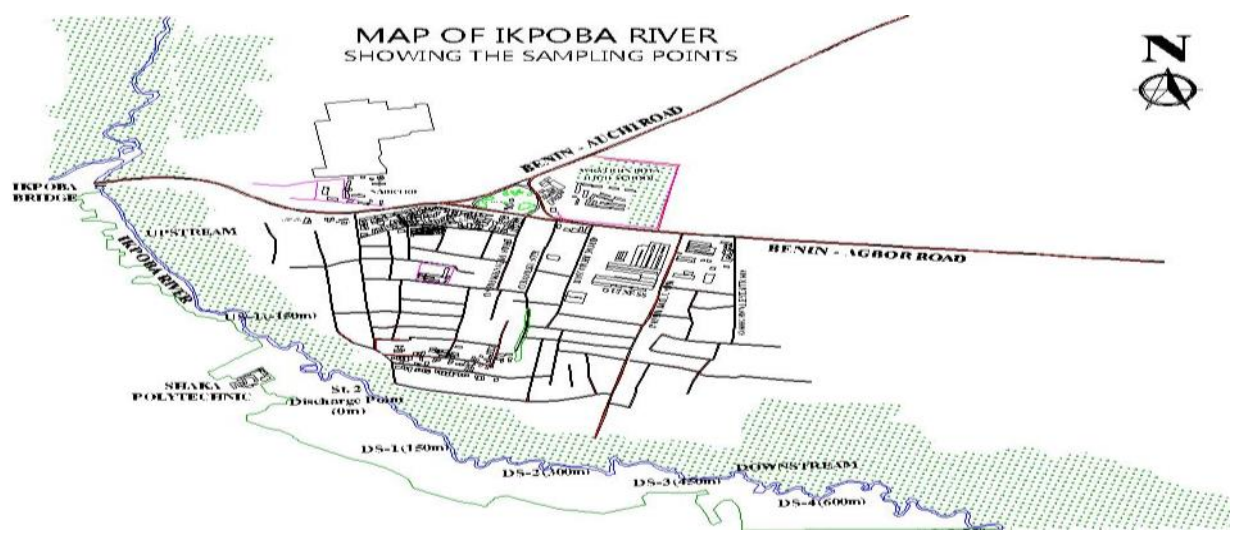

Figure 1. Map of Ikpoba River with sampling locations

\subsection{Sample Recovery and Chemical Analysis of Samples}

River water samples were collected twice in the months of October, November and December, 2014 at eight sampling locations within the river channel, which were used in monitoring the composition of waste discharged, the quality of the water at release (discharge) location and other sampling locations. Samples were collected in dry season so as to avoid considerable dilution, which comes with the rainy season. Sampling was done by washing the containers using the river water; thereafter the samples are collected and stored in cooler containing ice (ice chest). The twenty-five (25) physic-chemical parameters analysed were sodium, salinity, turbidity, electrical total soluble solids, total dissolved solids, biological oxygen demand, copper, chemical oxygen demand, colour, temperature, concentration of bicarbonate, chloride, phosphates, ammonia, nitrate, nitrite, nitrite iron, magnesium, calcium, cadmium, dissolved oxygen, conductivity, lead, $\mathrm{pH}$, nickel, vanadium, chromium and total hydrocarbon. The methods adopted for the laboratory analysis are those contained in the Standard Methods for Examination of Water and Wastewater (SMEWW, 2015).

\subsection{Quality Rating Computation}

Rating scale was assembled for set of values of each parameter. This rating ranged from $0-100$ and was shared in intervals of five. The rating $q_{\mathrm{n}}=0$ indicates severe pollution (the tested parameter indices surpasses the maximum allowable limit). Conversely, $q_{\mathrm{n}}=100$ is an indication that parameter indices available in the water has desirable values. Other ratings $\left(q_{\mathrm{n}}=40, q_{\mathrm{n}}=60\right.$ and $\left.q_{\mathrm{n}}=80\right)$ are within these extremes. These values represent excessive pollution, moderate pollution and slightly less pollution respectively. This is the modified version of the rating scale; it is calculated as follows (Ilaboya et al., 2014; Rocchini \& Swain, 2015):

$$
q_{n}=\frac{100\left(V_{n}-V_{i o}\right)}{\left(S_{n}-V_{i o}\right)},
$$

where, $q_{\mathrm{n}}$ is the quality rating or sun index, $V_{\mathrm{n}}$ is the test result for each parameter tested, $S_{\mathrm{n}}$ is the standard value of each parameter, $V_{\text {io }}$ is the ideal value of selected parameters tested in pure water, and $V_{\text {io }}=0$ for all parameters tested except $\mathrm{pH}$ and dissolved oxygen, which is 7.0 and 14.6 respectively.

The resulting value is multiplied by a weightage factor, which has significance to the water quality. The resulting sums are added to obtain one water quality index (WQI) for the water. It is a mathematical approach for the calculation of a unit number from various test results. The WQI calculated from the 
results, is a representation of the level of water quality in any given water body. The following steps were followed in the evaluation of the WQI in the river:

(a) the weightage unit $\left(W_{\mathrm{n}}\right)$ were determined for all tested parameters and added to get $\sum W_{n}$;

(b) the quality rating of all parameters tested were added to get $\sum q_{n}$;

(c) the index $W_{n}^{*} q_{n}$ was calculated for each parameter tested and summed up to obtain $\sum W_{n} \cdot q_{n}$;

(d) mass balance equation was used to compute WQI for each water sample as $\left(\sum W_{n} \cdot q_{n}\right) / W_{n}$; and

(e) the water quality index (WQI $=100-Z)$ was used to represent the level of water quality.

The computed WQI and other water parameters that was determined were exported into ArcGIS 9.3 software for the generation of spatial information for the dump yard.

\section{Results and Discussion}

The results of the twenty-five (25) physic-chemical parameters analysed from the samples recovered are presented in Table 2. Comparison was made between the results obtained and the permissible limits recommended in $\mathrm{WHO}$ guidelines. The variation of the various parameters with reference to the point of sample collection as well as the factors responsible for the variation was identified.

The wastewater samples collected in the sampling points apart from DP5 and DP7 were dark brown in colour with thick scum and offending pungent smell. The wastewater was characteristically acidic with an average $\mathrm{pH}$ of 6.45 while the temperature seems to be increasing although it was within the limit recommended by WHO and USEPA. Although the samples were recovered during the dry season (October, November and December), the total suspended solid value was high (16 -29); such values are usually obtained during wet season due to increase in flow from surface runoff, which brings more solids into the river. Table 2 also indicated that the hardness, calcium, manganese, magnesium, tin, barium, cyanide sulphide and sulphate concentrations were on the increase as a result of washing of mineral from adjoining areas, which are mostly farmlands and disposal sites by other industrial wastes.

Table 2. Result of chemical analysis on Ikpoba river sampling

\begin{tabular}{|c|c|c|c|c|c|c|c|c|c|c|}
\hline Parameters & DP1 & DP2 & DP3 & DP4 & DP5 & DP6 & DP7 & DP8 & $\begin{array}{c}\text { FEPA } \\
\text { Limit }\end{array}$ & $\begin{array}{c}\text { WHO } \\
\text { Limit }\end{array}$ \\
\hline Temperature & 34 & 38 & 31 & 27 & 38 & 24 & 33 & 23 & $<40$ & $<40$ \\
\hline Colour & 6.8 & 7.3 & 6.9 & 6.2 & 7.3 & 6.8 & 7.4 & 7.3 & 7 & 7.5 \\
\hline pH & 5.3 & 5.8 & 8.3 & 5.7 & 5.8 & 6.8 & 6.2 & 7.9 & $6-9$ & $6-9$ \\
\hline TSS & 27 & 27 & 22 & 26 & 20 & 16 & 27 & 29 & 30 & $<30$ \\
\hline TDS & 958 & 846 & 1036 & 931 & 582 & 758 & 899 & 748 & 2000 & $<1000$ \\
\hline Chloride & 571 & 386 & 264 & 483 & 260 & 352 & 474 & 306 & 600 & $200-600$ \\
\hline Sulphate & 684 & 455 & 538 & 488 & 472 & 594 & 827 & 523 & 500 & 1000 \\
\hline Sulphide & 1.19 & 0.94 & 1.35 & 0.61 & 1.13 & 0.42 & 1.37 & 1.39 & 0.2 & \\
\hline Cynide & 0.001 & 0.04 & 0.003 & 0.2 & 0.14 & 0.003 & 0.0012 & 0.001 & 0.1 & \\
\hline Nitrate & 16 & 14 & 8 & 15 & 9 & 6 & 4 & 6 & 20 & \\
\hline Phosphate & 3 & 3 & 4 & 3 & 1 & 2 & 2 & 3 & 5 & 10 \\
\hline Arsenic & 0.02 & 0.01 & - & - & 0.03 & 0.03 & 0.02 & - & 0.1 & \\
\hline Iron & 4 & 8 & 3 & 13 & 5 & 3 & 8 & 5 & 20 & $<15$ \\
\hline Manganese & 0.4 & 0.7 & 0.3 & 1 & 1.5 & 3.4 & 0.9 & 1.1 & 5 & 3 \\
\hline Calcium & 152 & 103 & 168 & 126 & 93 & 79 & 193 & 63 & 200 & $<100$ \\
\hline Magnesium & 3 & 3 & 1 & & 4 & 2 & 3 & 4 & & 10 \\
\hline Tin & 0.1 & 0.3 & 1 & 5 & 4 & 3 & 3 & 2 & 10 & 10 \\
\hline Barium & 0.7 & 0.4 & 2 & 1 & 3 & 3 & 2 & 1 & 5 & 5 \\
\hline BOD & 09 & 21 & 13 & 11 & 16 & 17 & 20 & 08 & $50-100$ & 50 \\
\hline Turbidity & 4 & 4 & 3 & 4 & 6 & 8 & 5 & 5 & $5 \mathrm{NTU}$ & $5 \mathrm{NTU}$ \\
\hline Hardness & 472 & 674 & 531 & 204 & 377 & 621 & 510 & 408 & 600 & $500-600$ \\
\hline Conductivity & 433 & 284 & 203 & 484 & 504 & 327 & 386 & 311 & 500 & 400 \\
\hline Cadmium & 0.002 & 0.0015 & 0.0012 & 0.0013 & 0.0013 & 0.0015 & 0.0014 & 0.0013 & 0.003 & 0.003 \\
\hline DO & 04 & 01 & 03 & 09 & 06 & 05 & 04 & 05 & 15 & 10 \\
\hline NTU: No true unit & & & & & & & & & & \\
\hline
\end{tabular}


Chloride concentration was fairly high while the Ammonia-Nitrate content fluctuated below the allowable limit specified by WHO. The alkalinity of the samples was quite low. This may be due to dilution whenever there is fresh wastewater released from the pollution source. The biological oxygen demand (BOD) indicates high variability, reflecting the time of waste discharge as the values obtained were far below WHO and USEPA limits. The effluent constituents portends a severe detrimental effect to aquatic organism in the stream and also a great danger to the downstream user of the stream. Although the turbidity values ranged from $3-8$, the high values obtained were indications that the stream is a recipient of divergent effluent, which affects it colour. The electrical conductivity apart from DP2 and DP3 has increased considerably in the river due to increasing concentration of various ions discharged into the river with the wastewater effluent. The industrial effluent discharge from Guinness brewery is also partly responsible for the increase in total dissolved solid (TDS) in the river.

The increasing pollution of the river body as shown in Table 2 have both environmental and public health implications. The environmental implication include foul smelling gases being emitted from the wastewaters, which pollutes the atmosphere with attendant health problems. Areas close to the wastewater courses also suffer from land degradation and inability to support plant growth. The polluted river also allow people to come into direct contact with the waste transported by the river, thus exposing them to various water borne and water related diseases. However, the sampling was designed to give a general picture of the nature and degree of industrial pollution of the river. It does not provide for continuous monitoring of the various parameters, nor does it allow for average parameter values to be obtained. The values obtained are 'grab sample values' at each time of sampling. The results are general in nature and does not represent average values for the river nor average locational values for the various parameters.

Table 3 shows the computed water quality index (WQI) from the laboratory results obtained from the tested samples; calculated WQI ranged from 40.020 in DP5 to 52.625 in DP6. Using National Sanitation Foundation (NSF) standard illustrated in Table 4, the river water in the sampled locations except DP6 and DP8 can be classified as bad.

Table 3. Calculated water quality index for the sampling points

\begin{tabular}{|c|c|c|}
\hline S/N & Location & Water Quality Index \\
\hline 1 & DP1 & 41.924 \\
\hline 2 & DP2 & 44.248 \\
\hline 3 & DP3 & 42.306 \\
\hline 4 & DP4 & 47.621 \\
\hline 5 & DP5 & 40.020 \\
\hline 6 & DP6 & 52.625 \\
\hline 7 & DP7 & 48.274 \\
\hline 8 & DP8 & 50.474 \\
\hline
\end{tabular}

Table 4. Classification criteria standard based on NSF

\begin{tabular}{|c|c|c|}
\hline NSF-WQI & Descriptor & Category \\
\hline $91-100$ & Excellent & A \\
\hline $71-90$ & Good & B \\
\hline $51-70$ & Medium & C \\
\hline $26-50$ & Bad & D \\
\hline $0-25$ & Very Bad & E \\
\hline
\end{tabular}

In order to reduce the level of pollution in the river, water pre-treatment facility should be provided for the treatment of industrial wastewater before discharge into the river. A stabilisation (facultative) pond, which is used for the biological treatment of wastewater was designed based on the result obtained from the investigation. The choice of facultative pond over aerobic and anaerobic ponds is its ability to accommodate both aerobic and anaerobic bacteria in the process of biological pre-treatment.

\subsection{Determination of Number of Ponds}

Temperature coefficient for cold season is determined using the following equation (Metcalf, 2003):

$$
k_{T}=k_{20} \theta^{T-20},
$$

where, $k$ is the reaction rate coefficient $\left(d^{-1}\right), \theta$ is the hydraulic detention time (d), and $T$ is the temperature $\left({ }^{\circ} \mathrm{C}\right)$.

$$
k_{20}=0.25(1.06)^{21-20}=0.27 d^{-1}
$$


The detention time for cold season condition for pond efficiency of $80 \%$ and a dispersion factor of 0.5 , is determined using value of $k t=2.4$ by Wehner $\&$ Wilhelm (Metcalf, 2003). Hence, $\left(0.27 d^{-1}\right) t=2.4$ and the detention time, $t=2.4 / 0.27 d^{-1} \approx 9$ days

Determination of number of Ponds. For $\mathrm{n}$ series of ponds:

$$
L_{e}=\frac{L_{i}}{(1+k t)^{n}},
$$

where, $L_{e}$ is the effluent $B O D, L_{i}$ is the influent $B O D$ while $n$ is number of ponds determined by the following equation:

$$
n=\frac{\log \left(L_{e} / L_{i}\right)}{\log (1+k t)} \text {. }
$$

Given that $L_{e}=348 \mathrm{mg} / 1, L_{i}=50 \mathrm{mg} / 1$ (obtained from laboratory test results), $k=0.27 d^{-1}$, and $t=9$ days, then the calculated number of ponds is 1.6. Therefore, two facultative ponds (in series) are required.

\subsection{Design of Facultative Pond}

Determination of pond volume and surface requirements; given a total population of 212,486; the flow discharge is deduced as follows:

$$
\begin{aligned}
& Q=200 \text { litre / person / city / day } \times 10^{-3} \times 212,486=42,497 \mathrm{~m}^{3} / \mathrm{d} \\
& Q \approx 42,500 \mathrm{~m}^{3} / \mathrm{d}
\end{aligned}
$$
days.

The volume of the pond is estimated using (5), where $V$ is volume, $Q$ is discharge while $t$ is time in

$$
V=Q t=42,500 \times 9=382,500 \mathrm{~m}^{3}
$$

For a pond of $2 \mathrm{~m}$ depth, the surface area $(A)$ is deduced as follows:

$$
A=\text { volumel depth } 382,500 / 2=191250 \mathrm{~m}^{2}=19.13 \text { hectares }
$$

Using three ponds in parallel, flow in each pond $=382,500 / 3=127,500 \mathrm{~m}^{3}$. Therefore, the surface area of each pond is $127,500 / 2=63,750 \mathrm{~m}^{2}$. Pond volume of $127,500 \mathrm{~m}^{3}$ is equivalent to $350 * 175 * 2.1$; that is, using a length to width ratio of 2:1. Hence, pond volume of $128,625 \mathrm{~m}^{3}$ is adequate.

Determination of the surface loading. The biological oxygen demand (BOD) expressed in $k g(h a-d)$ is given as follows:

$$
B O D_{5}(k g / h a-d)=\frac{Q^{*} B O D_{5}}{A},
$$

where, $A$ is the surface area in hectares $(b a)$ and $Q$ is the discharge $\left(m^{3} / d\right)$. By substitution,

$$
\begin{aligned}
& B O D_{5}(\mathrm{~kg} / \mathrm{ha}-d)=\frac{\left(42500 \mathrm{~m}^{3} / \mathrm{d}\right)\left(348 \mathrm{~g} / \mathrm{m}^{3}\right)\left(10^{3} \mathrm{~g} / \mathrm{kg}\right)^{-1}}{19.13} \\
& B O D_{5}=773.13 \mathrm{~kg} /(\mathrm{ha}-d)
\end{aligned}
$$

To check for the BOD removal, facultative pond effluent quality is deduced as follows:

$$
\begin{aligned}
L_{e} & =\frac{L_{i}}{(1+k t)} \\
L_{e} & =\frac{50}{[1+0.27(9)]}=14.6 \mathrm{mg} / \mathrm{l}
\end{aligned}
$$

\section{Conclusion}

From this research, the quality of water resources at the industrial wastewater discharge location has deteriorated over the period. This is directly attributed to the increasing discharge of industrial wastewater into the river. In most cases, the pre-treatment given to effluent by industries before discharge into the river is inadequate and this is in complete disregard of Federal Environmental Protection Agency Guidelines. This study therefore suggests that a detailed epidemiology should be carried out to ascertain the degree and extent of this environmental problem.

\section{Conflict of Interests}

Authors declare that there is no conflict of interests associated with this research. 


\section{Acknowledgment}

The authors sincerely appreciate members of staff of Water Resources and Environmental Engineering Laboratory of the University of Benin for their assistance during the analysis. Special thanks to Dr. R. Ilaboya for the support of analytical instruments. Authors also appreciate Prof. Bichi Mustapha Hassan for his works in water and river pollution.

\section{References}

Aikman, D. I. (2013). Wastewater reuse from the stand point of irrigated agriculture. The Public Health Engineering (IPHE), 2(1): 3541, London.

Anandalingam, G., \& Westfall, M. (2017). Hazardous waste generation and disposal: Options for developing countries. Natural Resources, 2(1): 37-47.

Benka-Coker, M. O., \& Ojior, O. O. (2015). Effect of slaughter house waste on the quality of Ikpoba River, Benin City, Nigeria. Bioresource Technolology, 52, 5-12

Bichi, M. H. (2013). Environmental Pollution in Kano: the contribution of wastewater discharge from Bompai, Sharada and Challawa industrial estate; Proceeding of Science Association of Nigeria Conference, Bayero University Kano, 1-8.

Bichi, M. H. (2015). Surface water pollution in the Kano industrial environment. Proceeding of National Workshop on Land Administration and Management in Northern Nigeria, Department of Geography, Bayero University, Kano, 10-17.

Centre for Science and Environment (CES) (2013). State of Indian's Environment: a citizen's report. Centre for Science and Environment, Delhi, 23-25

Dawood, R. (2016). Traveller's Health, Oxford Univ. Press, Oxford

Ekhaise, F. O., \& Anyasi, C. C. (2011). Influence of brewery effluent discharge on the microbiological and physicochemical quality of Ikpoba River, Nigeria, M.Sc. Thesis, Department of Microbiology, University of Benin, Benin City, Nigeria.

ESCAP (2011). Economic and Social Commission of Asia and Pacific; Quoted in World water, 4(8), ICE, London, pp7.

Gibbs, N. S. (2017). The turbulence of water, in Pickford, J. (ed), Developing world water, Grosvenor Press Int. London

Giddlings, J. C. (2003). Chemistry, man and environmental change, Canfield Press, Harper and RON Pub. Inc., San Francisco.

Hardoys, J. E., Mitlin, D., \& Satterth Waite (2012). Environmental problems in third world cities, Earth Scan, London

Ilaboya, I. R., Oti, E. O., Ekoh, G. O., Umukoro, L. O., \& Enamuotor, B. O. (2014). Assessment of water quality index of some selected boreholes around dump sites in Nigeria. International Journal of Environmental Monitoring and Protection, 1(2): 47-55

Leonard, H. J. (2004). Confronting industrial pollution in rapidly industrialisation countries - myths, pitfalls and opportunities: conservation foundation, Proceeding of National Association of Hydrological Sciences, Lagos Nigeria, 22 - 37

Metcalf Eddy (2003). Wastewater engineering, treatment, disposal and reuse, $2^{\text {nd }}$ edition, McGraw-Hill, New York.

Oluruntola, I. (2012). Battle over industrial effluents: Water Resources Journal, 1(1): 2-6.

Rocchini, R., \& Swain, L. G. (2015). The British Columbia water quality index, Water Quality Branch EP Department, B.C. Ministry of Environment, Land and park, Victoria, BC, Canada, 13-19

SMEWW (2015). Standard Methods for Examination of Water and Waste Water

United Nation Environmental Protection, (2017). Environmental Data Report 2017-2017: GEMS Monitoring and Assessment Research Centre; Blackwell, Oxford, 42-51 
